\title{
15
}

\section{INFRASTRUCTURES FROM BELOW}

\section{Self-Reproduction and Common Struggle in and Beyond Athens in Crisis}

\author{
Isabel Gutiérrez Sánchez
}

\section{Athens in Crisis: An Approach from Everyday Life and Urban Infrastructures}

In Greece, the multi-faceted crisis that ensued after the international financial crash of 2008 brought about extensive transformations to the economic and political orders as well as to people's everyday lives. From 2010 to 2018 a long series of austerity policies have been gradually implemented by successive national governments as a condition imposed by international creditors to receive bailout loans. Structural adjustment was delivered by means of curtailing salaries and pensions, increasing taxes, making cuts in the public sector, privatizing public infrastructures and assets, and decreasing welfare provision, as well as through the weakening of workers' and civil rights among other reforms. The austerity regime effectively translated into myriad processes of dispossessions and exclusions (Kalandides and Vaiou 2015). Its effects—still ongoing - have been devastating for the long-established institutions of provision of care and social protection, namely the state and the family. Importantly, austerity has especially targeted urban populations and areas, among which the Greek capital has borne the brunt. As the crisis endured, Athens was dragged into a perennial 'state of exception' as a result of increasing exclusions from social welfare and urban services and resources, privatizations, and sell-offs of public urban land and assets, and policing and repression, which have radically transformed the everyday life of many of its urban dwellers (Boano and Gyftopoulou 2016; Kalandides and Vaiou 2015; Stavrides 2014).

The continuing crisis in Greece can be seen as part of a far-reaching and long underway 'crisis of social reproduction.' Coming from Marxist and feminist traditions of thought, the notion of social reproduction refers to the labor that goes into the material and social sustenance of a group of people, both on a daily basis and generationally. It encompasses all the care practices that enable and sustain lives and livelihoods, as well as the structuring of the social relationships derived from those. Importantly, the conditions under which social reproduction takes place under capitalism are exploitative and often oppressive. This allows the very system to keep running and reproducing itself (Vega Solís et al. 2018). Today, after decades of neoliberalization of the economy and social life, and in the midst of an unprecedented ecological 
crisis as we are, many of the processes, spaces, and institutions that enable life, its sustenance, and its reproduction in our societies face a breaking point.

The crisis of social reproduction is systemic and manifests in different forms that intersect various domains, from the institutional to everyday life. Nevertheless, it is the latter arena where its destructive impacts are more easily traceable. Silvia Federici (2019) has asserted that in fact everyday life has become the very epicenter of this global crisis, as social reproduction is fundamentally grounded in this realm where structural conditions and inequalities are experienced individually and collectively. Certainly, the daily lives of growing populations are at present increasingly strained by dwindling salaries, precariousness, uncertainty, overwork, debt, the curtailing and privatization of public services, and the reduction of care work and resources. This juncture has put thousands of households at risk of poverty or social exclusion, while destroying countless communal experiences, spaces, and processes. Amid this climate of fear and insecurity, many have retreated to their private spaces. Thus, Federici (ibid.: 181) argues that everyday life, which she defines as "the primary terrain of mediation among people," has undergone a gradual emptying, and ultimately fallen into permanent crisis. For this reason, she advocates practices and processes contributing to the politicization of everyday life as a way of challenging the processes of economic restructuring, political suppression, and material dispossession enforced from above. Everyday life is also a paramount realm of practices of contestation, struggle, and imagination of forms of living, relating to one another, caring, and sustaining ourselves otherwise.

In cities, the crisis of everyday life is closely linked to urban infrastructures, because these infrastructures are central to the functioning of daily life. Negotiations with infrastructure are pivotal in the daily production, regeneration — or disruption — of the social life and social fabric of the city (Graham and McFarlane 2015). Arjun Appadurai (2015) contends that a closer look at the imbrications of materialities and socialities that infrastructures comprise, exposes the vulnerability of the negotiations and transactions that sustain the apparent normality of everyday life. In turn, a careful exploration of everyday actions also reveals how infrastructures are experimented with, reshaped, readjusted, re-purposed, and reimagined on a daily basis. In the same vein, AbdouMaliq Simone (2004: 407f) conceptualizes urban infrastructure as a "platform providing for and reproducing life in the city." Drawing on an ethnographic research in Johannesburg, the scholar coined the term 'people as infrastructure,' explaining that in engaging the "compounds of objects, spaces, persons, and practices" on a daily basis, people- "marginalized from and immiserated by urban life"- constitute themselves as infrastructure (ibid.: 407). These people's livelihoods and social life depend on and are determined by their capacity to understand, navigate, and negotiate these complex socio-material and spatial webs in constant flux. Simone's (2004) formulation stresses the relational character of infrastructures, while highlighting their role as (provisional) supporting structures of the everyday life in the city. Importantly, the scholar points out that 'people as infrastructure' is not a mere coping strategy, but also a means for the exertion of claims and the enactment of political imaginations. Thus, it constitutes a form of intervening in the existing, and ultimately a way of performing agency and yielding change in a given urban environment.

The anthropologist Dimitris Dalakoglou (2016: 822) observes a shift in what he calls the "paradigm of infrastructures' governance and function" in the current European context of chronic crisis. He sees this turn being pushed from below by citizen-led networks, which are transforming the ways in which urban infrastructures are managed, perceived, and imagined. Amid crisis, people are re-composing infrastructural platforms that allow them to sustain their 
very everyday lives while advancing new forms and imaginations of urban life. This chapter attends to this juncture by focusing on Athens during the austerity regime and some of the solidarity structures created by grassroots groups in response. Its aims are to 1) present ways in which these groups reconfigure care practices and reorganize everyday social reproduction on their own terms and spaces, and 2) reflect on the impact and potentiality of the infrastructures they create in the everyday life of Athens in crisis and beyond.

\section{Resistance, Struggles, and (Re)Organizations of Social Reproduction}

Despite the destructive consequences brought about in and through the crisis in Athens, the rampant processes of exclusion and dispossession have not gone without fierce contestation. People have struggled - and continue to do so-to meet their needs, and also against the austerity regime enforced upon them. In fact, since the early months of economic recession, citizens took massively to the streets to protest. Over time, thousands coming from different social backgrounds have mobilized, dissented, and eventually self-organized to cope with and fight back against the devastating impacts of austerity on everyday lives, welfare, and liberties. In May 2011, Syntagma Square was occupied for over a month. The occupation provided the supporting infrastructure for a growing movement demanding a radical political and economic overturn, becoming a truly social experiment of self-organization based on direct democracy and mutual support. The experience of Syntagma took roots in many neighborhoods, fostering the emergence of numerous neighborhood committees, cooperative economy structures, and so-called 'solidarity initiatives' (Arampatzi 2016, 2017; Rübner Hansen and Zechner 2015a, 2015b).

Social kitchens, community clinics and pharmacies, networks of care services, training and language classes, accommodation centers for/with migrants and refugees, legal aid hubs, and mobile laundries became part of a blossoming geography of self-organized structures, which brought together people of different origins, ages, and economic and political backgrounds. Some of these projects were short-lived, while others have continued into the present. Nonetheless, common to all of them was - and still is - an intrinsic political character. Solidarity initiatives frame their very existence simultaneously as a struggle for survival and of assertion of their rights to welfare. Namely, they combine the provision of everyday survival needs with participation in broader struggles over social reproduction and civil rights. As such, their praxis cuts across several scales. They claim their right to care and be cared for at the institutional level, while at the same time actively performing this right in everyday life. Whether currently active or not, as a movement, solidarity initiatives have crucially contributed to bring the pressing issues of social reproduction to the forefront of the political struggle, effectively turning this realm into an arena of contestation and reorganization (Rübner Hansen and Zechner 2015a, 2015b).

In what follows, I will outline how these grassroots collectives articulate the two-fold praxis of integrated social reproduction and struggle by drawing on an ethnographic research conducted between 2016 and 2019 in three of these solidarity initiatives, namely a social kitchen, an accommodation center with migrants and refugees, and a community center. The following ethnographic accounts focus on their functioning as infrastructure and on the spatialities they produce, and seek to articulate a reflection around the impact of the initiatives on the urban dynamics and territories, as well as on political implications of their multi-scale praxis. 


\section{Solidarity Initiatives: Emerging Infrastructures and Spatialities}

Despite the increasing dispossessions, exclusions, enclosures, and suppression in a city ruled by austerity, many of the citizen-led initiatives that emerged in the wake of the Syntagma occupation took hold and have eventually thrived. The understanding of urban space- and their right to it — as necessary and indeed fundamental to their struggles was key for these processes. Set up through spatial re-appropriations, re-configurations, and re-purposing of urban spaces in Athens in crisis, the institution and development of solidarity initiatives actually entailed the subversion and creation of new forms of urban infrastructures - in the sense of the understanding outlined above (see Appadurai 2015; Dalakoglou 2016; Graham and McFarlane 2015; Simone 2004) —namely, as socio-material complexes that sustain everyday life, through which different social actors enact and invent political imaginations. The three initiatives that will be presented below provide diverse examples for ways of reclaiming, reimagining, and transforming the use, management, and meaning of urban infrastructures. Starting from the first settling-in, the three of them developed a daily praxis that very much can be characterized by Simone's (2004) notion of 'people as infrastructure.' This infrastructural character marked both their respective internal and external functioning. Notably, this relational praxis is inherently spatial, namely partakers in the initiatives transform and produce space; from temporary instances that blur the borders between the public and the private that structure everyday life, to new urban geographies. The emerging spatialities and geographies in turn reflect the precarious, tentative, temporary, and also subversive character of daily practices of the collectives' participants.

\section{O Allos Anthropos Social Kitchen}

The social kitchen O Allos Anthropos [The Other Person] was initiated in 2012 with the objective of providing free food for any person in need. The collective started setting up a makeshift kitchen on a daily basis in different public spaces across the city, where members of the collective cook and eat together with the people they serve. Initially, O Allos Anthropos set up its headquarters in an industrial building in the Metaxourgeio neighborhood of central Athens. The building was rented and refurbished to accommodate a kitchen and a pantry, clothing storage, a computer area, a space for school support activities, a space for meetings and gatherings, and restroom facilities. It also served as a shelter for homeless people, offering free baths and sleeping accommodation. The headquarters were relocated several times, the last one being in 2019 to premises in the neighborhood of Keramikos.

The scene in Figure 15.1 was drawn on a summer day when the collective set up the kitchen on a square in the city center. As can be seen, the scene is full of movement. Just by informally installing a simple folding table and a big pot, the group provisionally creates a common space, while breaking the traditionally established private-public boundary. The street is turned into a temporary open domestic space where meals are cooked and shared. Spontaneous activities like ball games, live music concerts, puppet shows, and dances emerge around the kitchen - sometimes to the suspicion or discomfort of patrolling police officersaccompanying and amusing the chefs on duty and attracting more people.

Behind this snapshot of cooking and serving food in such a bustling atmosphere are quite extensively coordinated processes and work. The whole process starts with making calls for food and monetary donations via a website and social media. Donations can be made either 


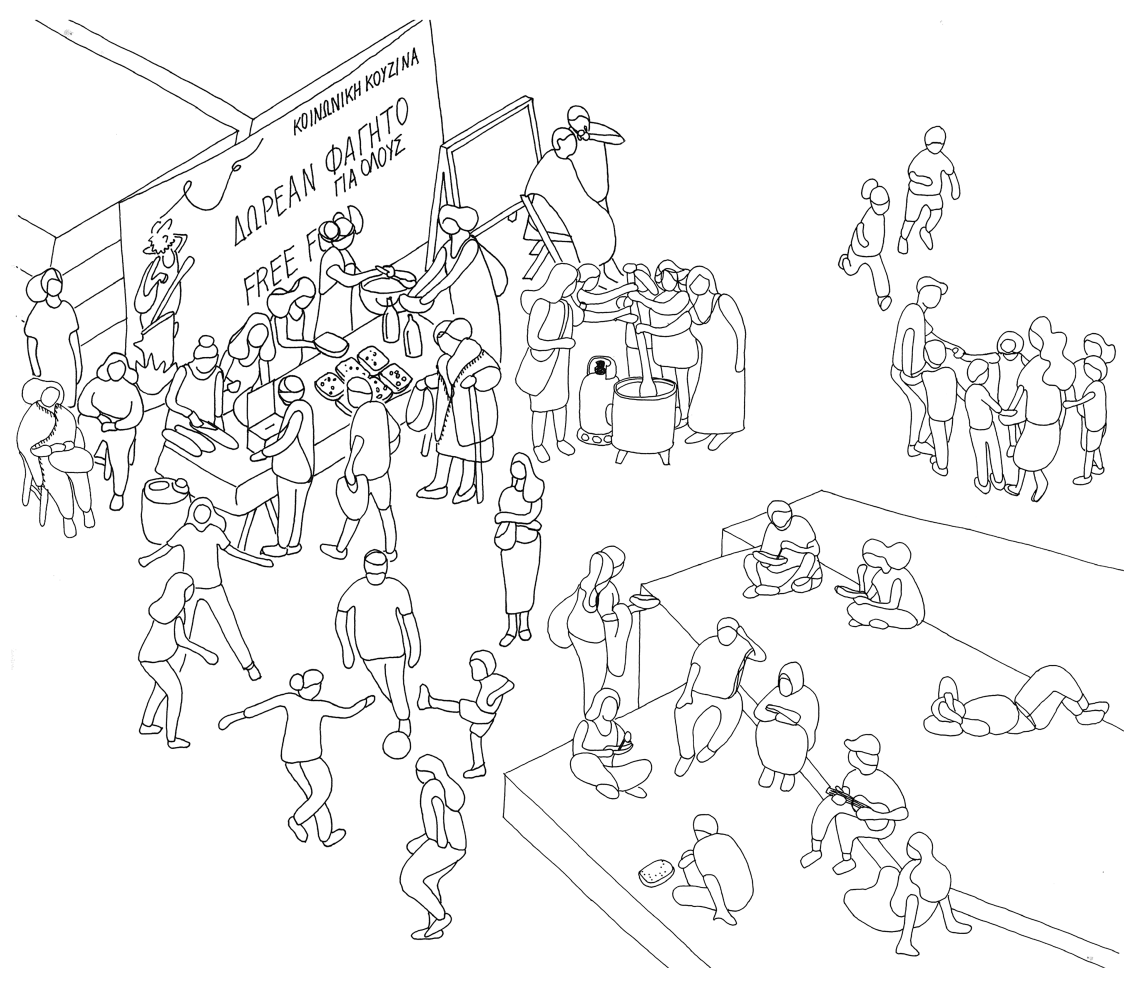

FIGURE 15.1 O Allos Anthropos social kitchen at Monastiraki Square, summer 2016. Source: Isabel Gutiérrez Sánchez, 2016.

by personal arrangement with the core members of the group or by bank transfer. The core team picks up the food or buys it at wholesale markets and brings it to the social kitchen's headquarters to store it in the pantry. Each day, several members take the responsibility for bringing the food together with the kitchen equipment - the mobile stove, the gas cylinder, the casserole, the wooden ladle, the folding table, the tablecloth, the banner, the plastic cutlery, and the disposable dishes - to the corresponding site in the city. At the end of the event, after cleaning up, someone returns the equipment to the headquarters.

In addition, $O$ Allos Anthropos exchanges resources at the local level with other self-organized kitchens, as well as with social clinics and self-organized migrant/refugee centers. They are also connected to several 'without-middlemen' networks of food distribution and an urban orchard initiative in the neighborhood of Haidari in western Athens, which provides them with vegetables. Some of its members engage with various political groups that organize protests, campaigns, and/or solidarity actions with political activists, migrants, and refugees; and some have built connections with migrant/refugee initiatives based in other European countries like Spain and Germany. At a national and an international level, O Allos Anthropos is part of a network of other social kitchens. From time to time, some of them schedule videocalls to have a sort of translocal meal shared among several social kitchens from afar. The attempt to bring people together and build new connections is a constant in the initiative. Parties are particularly popular. At the time of my fieldwork, the collective used to celebrate a big barbecue with live music and dance at least once a year in the street adjacent to the social 
kitchen's headquarters, succeeding in bringing together hundreds of people-among them neighbors, families, and children. They also organized smaller get-togethers to collectively celebrate religious festivities like Ramadan or Christmas.

\section{City Plaza Refugee Accommodation Center}

City Plaza, a refugee accommodation center, was founded in April 2016 after a group of local activists and refugees squatted an eight-story hotel, which had been abandoned for years in the area of Victoria in central Athens. The group sought to create simultaneously a space of shelter for migrants and asylum seekers newly arrived in Athens, and a space for people involved in local struggles of different kinds to meet, exchange, and organize. Within a few days, the building was 'adapted' to accommodate around 400 people. Both private and shared rooms were cleaned and arranged for families and single persons, while the reception, the kitchen, a large dining room, a cafe, a stock room, and a doctor's office and dispensary were put into operation. Over time, a number of other spaces were also re-purposed to accommodate classrooms, workshops, a library, a playground area, spaces for communal celebrations and parties, assemblies, talks with guests, film screenings, and/or just casual gatherings.

Figure 15.2 shows a typical day in the kitchen. Everyday organizing depended on the available food, mostly ensured through donations. People took on interchangeable roles and tasks as chefs, assistants to chop vegetables or meat, servers, or cleaners. Music normally animated the daily work creating a pleasant and relaxed atmosphere. Times for breaks, chats, or a smoke on the balcony were plenty. Supporting the daily functioning of the kitchen, there were a number of logistic operations, which certainly required a great deal of work. Everyone in the house contributed somehow, from children to grown-ups. Several times, I was able to

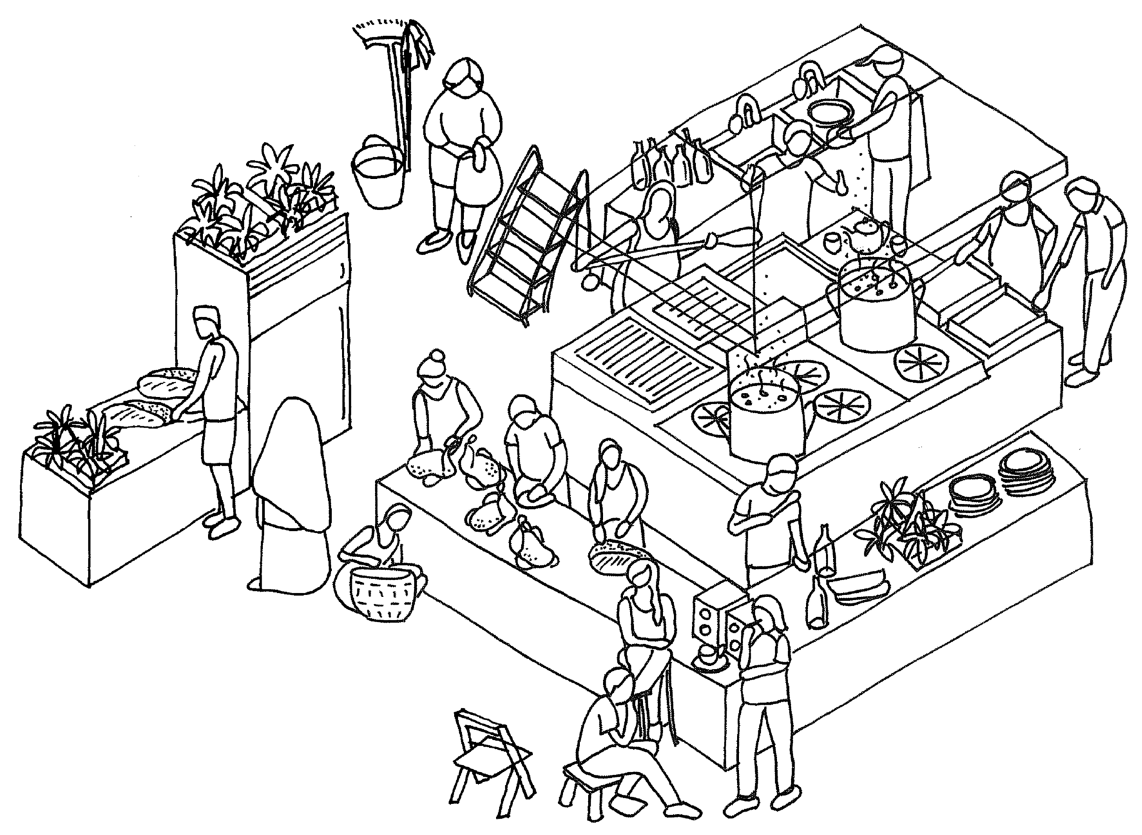

FIGURE 15.2 City Plaza kitchen, summer 2016. Source: Isabel Gutiérrez Sánchez, 2016. 
take part in the human chains that were made up when a new delivery arrived at the door of the building, an event that was loudly announced by children running from the first to the top floor, spreading the news. They were usually the first and certainly the most eager to contribute in the chains, smiling and sometimes singing while passing from hand-to-hand watermelons, juice or milk jars, boxes of clothing, and even new furniture or equipment like baby strollers, which were added to the common fleet arranged on the first floor for the use of parents and child-carers.

Occasionally, residents hosted open celebrations and parties. They invited non-residents to show them their home. An anniversary party was organized at the squat every April. Religious festivities, the arrival of newborns, and birthdays were also quite regular occasions for collective celebration. A big collective meal was once held at the entrance of the building-for which a long table was set taking over the entire length of the small street, filling it with conversations between residents, friends, and neighbors and with a culinary display by an association of African women who offered their work for the event. Almost daily, bedrooms became improvised kitchens-as depicted in Figure 15.3-where neighbors gathered to have a meal or tea together. There were times when balconies served as kitchen tables where homemade pasta and bread dough were prepared. Keeping the tradition of their home cities in countries in Africa and the Middle East, some families left the door of their rooms open or replaced the door with a makeshift curtain. Shoes were lined up along the newly crafted entry, creating a small hall or passage in-between the outer corridor and the interior of the rooms.

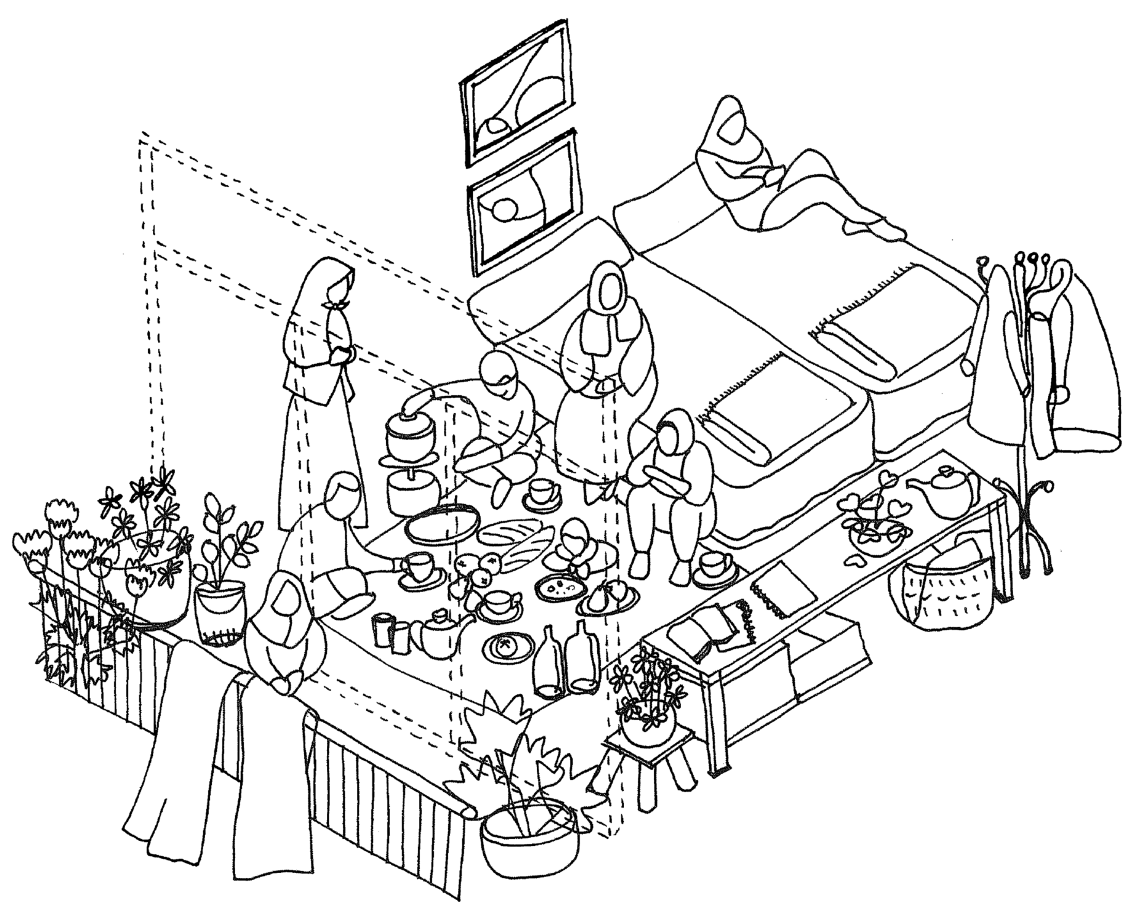

FIGURE 15.3 Residents' gathering in a family room in City Plaza, winter 2017. Source: Isabel Gutiérrez Sánchez, 2017. 
The creation of new spaces challenging established uses and boundaries was indeed a common practice in City Plaza. However, there were also moments in which these stretching/ opening-up operations reversed, as for instance when residents closed the doors and guarded the building against a potential attack by far-right groups, or when assemblies were closed off to non-residents - or even to specific residents - to deal with certain issues. These instances reflected the significant external threats, as well as the internal dilemmas that the squat faced from its very inception.

City Plaza was active for 39 months. In July 2019, all residents left the building voluntarily. During its lifespan, City Plaza provided safe and dignified accommodation for 2,500 refugees and asylum seekers from 13 different countries, as well as dozens of so-called international 'solidarians.' Besides, it attracted hundreds of political activists. In fact, the initiative had a close relationship with different political groups as well as with other housing squats for/with migrants and refugees, social clinics, self-run mobile laundries, food, clothing and hygiene products distribution groups, independent education collectives, an independent solidarity information technology collective, and a mobile library. The activists were also well connected with international groups and platforms which also defend migrants and refugee rights. They collectively hold rallies for which they used to display a full range of self-made placards, flags, and banners. The use of a wide array of social digital media, including public accounts, newsletters, websites, and blogs through which they posted news, announcements, reports, reflections, statements, and calls for solidarity actions, was key for these networking purposes.

\section{Khora Community Center}

Khora is a self-organized community center-currently split into several service-specific settings under the legal form of a cooperative foundation — which was set up in 2016 by a group of international volunteers. As stated by the group, the center's name took its meaning from one of the definitions of the Greek word Xẃpa, which designates "a radical otherness that 'gives place' for being" (Khora 2016, original emphasis). Khora's foundational statement was grounded in a rejection of the European Union border system and its migration policies, as well as in the attempt to create structures of support and solidarity with and among migrants and refugees as a counter-response. It was first located in a former six-story industrial building in the Exarcheia neighborhood in central Athens. The entire building was refurbished to accommodate a welcome area and a children's space, a clothing storage and free-shop, a kitchen and a food storage, a cafe with a stage, several classrooms and a library, legal support offices, a dental practice, an area for craft workshops and music lessons, a women's space, and a rooftop garden. Most of the new partitions and furniture were designed and constructed in a wood and metal workshop, which was set up in the basement. This building was closed in summer 2018. During its two initial years, Khora provided a space for people from different backgrounds to socialize, work together, and learn. On average, there were around 150 volunteers. Khora worked in collaboration with different legal aid organizations providing asylum support, translators, independent education groups and artists collectives, local consumer and food distribution groups, clothing and primary need products supply groups, local free-shops, a mobile laundry, independent NGOs and charities both local and international, and other migrant/refugee initiatives in Greek islands and abroad.

Similar to City Plaza, the everyday running of the space involved extensive organizing operations. For instance, it used to take arranging and coordinating four weekly working 


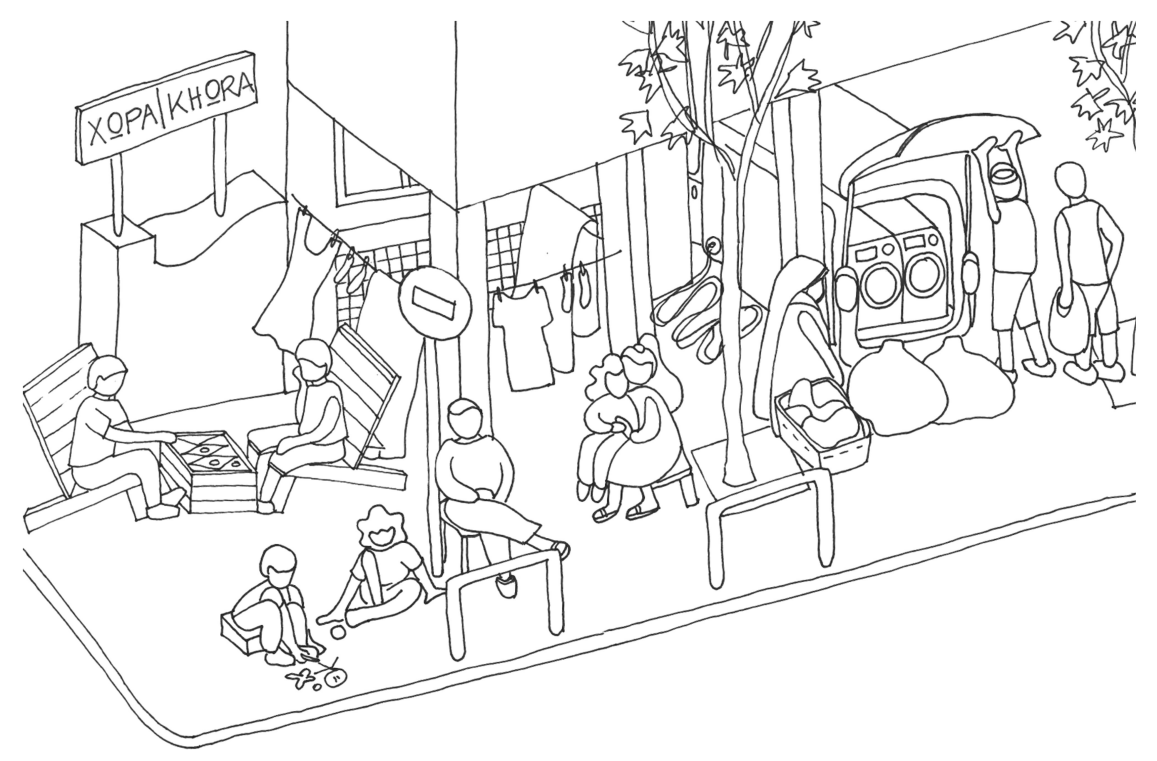

FIGURE 15.4 Outside the Khora building on a day when the mobile laundry serves the center, summer 2017. Source: Isabel Gutiérrez Sánchez, 2017.

groups, namely the administration/media team, the van team, the sorting team, and the shop assistants team, in different shifts, for donated clothing to be handed to individuals and/or families at the free-shop. The administration/media team launched calls for clothing donations via social media and arranged collection with the corresponding donors. In the cases where the collection required a means of transportation, the van team used a rented van. In the basement, the sorting team classified, fixed, and organized the collected clothing on shelves, tables, and cabinets. The shop assistant's team arranged different times for people to come and get clothes. In order to sustain this process, once in a while the center closed its doors for a couple of days to carry out maintenance- - both of the building and/or of 'the community.'

Figure 15.4 represents the passage facing the workshop of the building located on the ground floor. The days when the laundry van served the community center, people gathered and lingered in this liminal space for hours. Self-designed chairs and tables have been taken out to this passage so people could have a chat and a coffee, a smoke, or a game of backgammon, while waiting for the laundry to finish. Sometimes clothes were hung on ropes to dry, adding new layers to this temporary urban threshold in which the domestic spilled over onto the street. Similar to O Allos Anthropos and City Plaza, activities in Khora used to expand way beyond their respective main locations. Collective activities outside the building ranged from 'pot-luck picnics' to excursions, 'beach clean-ups,' or basketball games on the courts available in the neighborhood. They organized numerous parties and invited locals and neighbors.

\section{Infrastructures from Below: Beyond Everyday Life in Crisis}

The previous accounts have attempted to provide some insights into the daily functioning of the three examined solidarity initiatives set up in Athens during the crisis, and the nature of the spaces that emerged out of their praxis. A relational logic of interdependence and 
exchange becomes apparent from the very onset of the projects from the daily transformations of the spaces in response to emerging needs or desires, to the way people coordinate everyday work, and to the continuous effort to network with other supporting groups. Care, collaboration, reciprocity, and commoning of information, skills, and resources are all fundamental practices that shape and hold the everyday life of these self-organized collectives. Thus, following Simone (2004), I have argued that people in these initiatives operate as infrastructure; for defining and self-organizing their own operational terms and scope of action, they take active part in the production, use, management, and imagination of new (unsettled) structures that enable and sustain life in the city. Furthermore, in line with Dalakoglou (2016), I contend that these projects of integrated, self-organized reproduction and common struggle actually (re)configure urban infrastructures in different ways, which in turn have specific implications for the city itself.

On the one hand, solidarity initiatives transform buildings and urban spaces-mostly in states of disuse or neglect-into operative platforms of services supporting everyday needs and practices. Their praxis involves the reclamation, reconfiguration, and reactivation of urban space. They introduce new uses in the urban public through the collectivization of many social reproduction activities, many of which have traditionally been considered domestic, and thus private. By re-purposing those sites with functions of social reproduction-organized and delivered on a basis of commoning - they make life sustenance a public - and visibleconcern, hence contribute to the politicization of social reproduction in the everyday. In addition, their activities expand and contract in urban space, diluting boundaries between the established private and public spheres, and challenging urban borders and enclosures. Thus, as noted by Ares Kalandides and Dina Vaiou (2015), through their daily practices, solidarity initiatives reconfigure the very notion, boundaries, and materiality of (urban) public space, which takes on new meanings, dimensions, and temporalities. In other words, while daily performing their right to care and be cared for, these grassroots collectives expand the very urban public, too. In a city where increasingly public services, assets, and spaces are being targeted for sell-offs and privatizations, practices reclaiming and re-appropriating spaces for the social reproduction of its inhabitants become fundamental means to fight back.

On the other hand, over the years of enduring crisis, solidarity initiatives have managed to sustain a safety net based on a decentralized infrastructural system of networks across metropolitan territories and beyond. The resulting geography reflects many of the outlined characteristics of the nature of the initiatives themselves. It is decentralized, uneven, and of course, unplanned. Sometimes this geography is 'hidden,' as many of the nodes do not mark or visibly name the buildings or spaces they inhabit for political and/or safety reasons. For the most part, this geography is not registered in the (public) databases of municipalities. It is unsettled and precarious; some of the nodes are just provisional, or short-lived, or appear and disappear intermittently - whether due to economic strains, external political pressures and repression, or internal issues. Last but not least, it is contentious and insurgent. In fact, by acting as infrastructure, not only do these solidarity initiatives enable the conditions for inhabitation and the reproduction of everyday life in the city, but they also generate new connections with other groups, opening the potentiality for new ways of organizing and spreading resistance. They actually yield processes through which disposed, excluded, and/or alienated urban dwellers collectively claim and enact their right to actively participate and transform their urban environment, becoming a force of action in the city. In an Athens in crisis, solidarity initiatives - the infrastructures from below they compose and the urban citizen-led safety net they 
integrate - challenge the logic of deprivation, separation, enclosure, and suppression enforced from the top-down during - and by means of - the austerity regime, opening up other possible urban imaginations and other forms of everyday life beyond crisis.

\section{References}

Appadurai, A. (2015) Foreword. In S. Graham and C. McFarlane (eds.) Infrastructural Lives: Urban Infrastructure in Context. New York: Routledge, pp. xii.

Arampatzi, A. (2016) The Spatiality of Counter-Austerity Politics in Athens, Greece: Emergent "Urban Solidarity Spaces". Urban Studies 54(9): 2155-2171.

Arampatzi, A. (2017) Contentious Spatialities in an Era of Austerity: Everyday Politics and Struggle Communities in Athens, Greece. Political Geography 60(5): 47-56.

Boano, C. and Gyftopoulou, S. (2016) Crisis-Ridden Space, Politics, and the Social Imaginary:The Case of Athens. Critical Planning 22(3): 67-97.

Dalakoglou, D. (2016) Infrastructural Gap. City 20(6): 822-831.

Federici, S. (2019) Re-Enchanting the World: Feminism and the Politics of the Commons. Oakland: PM Press/ Kairos.

Graham, S. and McFarlane, C. (2015) Introduction. In S. Graham and C. McFarlane (eds.) Infrastructural Lives: Urban Infrastructure in Context. New York: Routledge, pp. 1-14.

Kalandides, A. and Vaiou, D. (2015) Practices of Collective Action and Solidarity: Reconfigurations of the Public Space in Crisis-Ridden Athens, Greece. Journal of Housing and the Built Environment 31(3): 457-470.

Khora (2016) About Us. Khora Athens [Online]. Available at https://www.khora-athens.org/about [Accessed 3 May 2020].

Rübner Hansen, B. and Zechner, M. (2015a) Building Power in a Crisis of Social Reproduction. Roar Magazine 7: 132-151.

Rübner Hansen, B. and Zechner, M. (2015b, August 20) Social Reproduction and Collective Care. The Occupied Times of London [Online]. Available at: http://theoccupiedtimes.org/?p=14000 [Accessed 3 May 2020].

Simone, A. (2004) People as Infrastructure: Intersecting Fragments in Johannesburg. Public Culture 16(3): 407-429.

Stavrides, S. (2014) Emerging Common Spaces as a Challenge to the City of Crisis. City 18(45):546-550.

Vega Solís, C., Martínez Buján, R. and Paredes Chauca, M. (2018) Introducción: Experiencias, Ámbitos y Vínculos Cooperativos Para el Sostenimiento de la Vida. In C.Vega Solís, R. Martínez Buján and M. Paredes Chauca (eds.) Cuidado, Comunidad y Común: Experiencias Cooperativas en el Sostenimiento de la Vida. Madrid:Traficantes de Sueños, pp. 15-50. 
$\because$ Taylor \& Francis Taylor \& Francis Group http://taylorandfrancis.com 